\title{
Effect of Kokum (Garcinia Indica) Rind Extract With Honey on Chronic Gastritis: A Randomized Controlled Trial
}

\author{
Swathi B.S ${ }^{1 *}$, Prashanth Shetty ${ }^{2}$, Geetha B Shetty ${ }^{3}$ \\ 1- PG Scholar, Department of Diet and Nutrition, SDM College of Naturopathy and Yogic Sciences, Ujire, Karnataka, India \\ 2- Ph.D. in Yoga, Principal SDM College of Naturopathy and Yogic Sciences, Ujire, Karnataka, India \\ 3- MD in clinical Naturopathy, Dean Division of Department of Diet and Nutrition, SDM College of Naturopathy and Yogic Sciences, Ujire, Karnataka, \\ India.
}

\section{A B S T R A C T}

Background and Objectives: Chronic gastritis is a chronic inflammation of gastric mucosa associated with various degrees of damages to superficial and glandular epithelia. Garcinia species are evergreen tropical shrubs, cultured in North-Eastern India and Southeast Asia. In Indian traditional medicine, the kokum fruit rinds are used to treat various inflammatory diseases such as gastric ulcers and bowel complaints caused by Helicobacter pylori infection. The objective of this study was to assess effects of kokum rind extract with honey on symptoms and life quality of individuals with chronic gastritis as well as their effects on gastric myoelectrical activity.

Materials and Methods: 60 chronic gastritis patients were randomly gategorized into two groups. Experimental group $(n=30)$ received $10 \mathrm{~g}$ of kokum rind extract with $18 \mathrm{~g}$ of honey twice a day and control group $(n=30)$ received $200 \mathrm{ml}$ of warm water twice a day for three weeks. Electrogastrogram, Izumo scale questionnaire and gastrointestinal symptom questionnaire were used at the baseline and on Day 21. Data analysis was carried out using R Statistical Software v.3.6.0.

Results: Significant decreases in gastrointestinal symptoms were observed in experimental group verified by gastrointestinal symptom questionnaire $(p<0.0001)$, compared to control group $(p=0.2879)$. Izumo scale questionnaire for quality of life assessment showed significant improvements with $p<0.0001$ in experimental group. The mean decreases in dominant frequency of electrogastrogram were higher in experimental group $(p<0.0001)$, compared to control group $(p=0.1511$, which suggested improvements in gastric myoelectric activity.

Conclusions: Kokum rind with honey is a cost-effective treatment to decrease symptoms of chronic gastritis, which can be considered as a safe home remedy.

Keywords: Kokum rind extract, Honey, Chronic gastritis, EGG, GISQ

\section{Introduction}

Functional gastrointestinal diseases are considered as major problems to public health because they are significantly common and induce major socioeconomic burdens. The severity of these diseases is affected by intestinal and extra-intestinal symptoms, psychological distresses and quality of life (QoL) (1). Chronic gastritis is a chronic inflammation of gastric mucosa, which is associated with various degrees of damages to superficial and glandular epithelia (2). Globally, more than half of people may have chronic gastritis. Helicobacter $(H)$ pylori infection in childhood is the major cause of chronic gastritis (3). There are numerous other causes such as viral and bacterial infections, reactive inflammations due to bile and pancreatic juice refluxes, non-steroidal antiinflammatory drugs (NSAID), alcohol consumption, chemotherapy and autoimmune responses against parietal cells as well as other rare causes such as post-radiation and stress-induced inflammations (4). Proton pump inhibitors (PPIs) have been used as effective therapies in management of chronic gastritis. Sufficient evidence reveal that PPIs are associated with serious adverse effects, especially at high doses. Majorly, PPIs are metabolized by hepatic microsomal enzymes with inhibitory effects (5). Acid peptic disease is more common in age groups of 18-59 years (6). In India, almost $80 \%$ of the population are infected by $H$. pylori, mostly by ten years. Triple therapy 
now fails because of the bacterial resistance. Hence, newer remedies and agents are needed to fight increasing prevalence of $H$. pylori linked gastritis (7). Garcinia species are evergreen tropical shrubs, which are grown in NorthEastern India and Southeast Asia (8). Garcinia indica (kokum) fruit rind can be one of these alternative therapies, which includes potential anti-inflammatory, anti-bacterial and anti-ulcer activities (9).

Honey is a natural product with antibacterial and healing properties (10). Kokum juice is used as a natural remedy for stomach and liver disorders (11).In Indian traditional medicine such as Ayurveda, fruit rinds and leaves are used to treat various inflammatory diseases such as gastric ulcers and bowel complaints. Chemical studies have shown that the herbal rinds contain proteins, tannin, pectin, sugars, fats, ascorbic acid, organic acids (22.8\%) such as hydroxy citric acid, hydroxy citric acid lactone and citric acid, anthocyanins $(2.4 \%)$, cyanidin-3-glucoside and cyanidin-3sambubioside, garcinol and iso-garcinol and $30 \%$ of moisture contents (12). Kokum juice is mixed with yogurt and salt to make a natural antacid (13).Garcinol present in the rinds shows potential antimicrobial activities. It plays important roles in treatment of gastric ulcers caused by $H$. pylori chronic infections (14). Honey naturally shows , protectections against gastrointestinal infections, healing properties on ulcers (peptic ulcer disease) and antibacterial, antiviral, antifungal and anti-inflammatory activities and acts as a prebiotic and an antioxidant. Gluconic acid, acetic acid, formic acid and citric acid are detected in honey, controlling inflammations and promoting healings (15).These organic acids are responsible for the acidic properties of honey (16). Studies have verified that honey with the triple therapy has shortened necessary times to eliminate H. pylori infections (17). Considering limited studies in this area and lack of clinical trial-based evidence, the current study investigated efficiencies of honey and kokum rind extract on symptoms and QoL in individuals with chronic gastritis.

\section{Materials and Methods}

Study design: This randomized, controlled trial study included three weeks in Nature Cure Hospital, Shanthivana, Dharmasthala, Karnataka, India. The study received the institutional ethics committee approval (Registration No. EC-219). All the patients were provided with written informed consents in their local language.

Patients: Totally, 100 pre-diagnosed chronic-gastritis patients were screened. Of these patients, 60 patients of 20-50 years old, (6) from both genders participated in the study based on inclusion and exclusion criteria. The participants were categorized into experimental $(n=30)$ and control $(n=30)$ groups using the lottery method of randomization. These participants were recruited from OutPatient Facility, SDM College of Naturopathy and Yogic
Sciences, Ujire, as well as suburbs of Ujire, Dharmasthala and Venoor (Karnataka). Participants were assessed using gastrointestinal symptoms questionnaire (18) and their detailed histories were collected. Patients with the following conditions were excluded from the study: peptic ulcers, administrated antacids for the past two months, inflammatory bowel disease (IBD) and gastric and colorectal cancers. Furthermore, patients with other comorbid conditions such as diabetes mellitus and renal diseases and those who were not willing to participate in the study were excluded from the study.

The mean age of the participants included $34.33 \pm 9.02$ years in experimental and $28.40 \pm 9.81$ years in control groups. In total, $24(40 \%)$ males and 36 (60\%) females participated in the study. In general, 30 participants were set in each group that ten males and 20 females were in experimental and 14 males and 16 females in control groups.

Sample size: A few preliminary studies have included 30 participants as the minimum sample size in each group, which was suggested based on the thumb rule and central limit theorem (19). Therefore, 30 participants in each group were set as the sample size of the present study.

Intervention: Participants in experimental group received kokum rinds, which were collected from Dakshina Kannada District, then it was dried by solar drying method (20) Honey was collected from honey society, Puttur, Dakshina Kannada District. In general, $10 \mathrm{~g}$ of kokum rinds were soaked in $200 \mathrm{ml}$ of water for 7-8 h. Then, the soaked water was mixed with $18 \mathrm{~g}$ of honey and consumed at early mornings and evenings (21, 22). Instructions included fasting half an hour before and after drinking the juices. Control group was asked to drink $200 \mathrm{ml}$ of warm water twice a day (23). No adverse events were recorded during the study.

Assessment: The assessed variables included severity of symptoms of the disease, QoL and gastric myoelectric activity.

Gastrointestinal symptoms questionnaire: The questionnaire was used to assess changes in the symptoms linked to chronic gastritis (18). Izumo scale questionnaire (including 15 items in five domains of reflux, pain, fulness, constipation and diarrhea with three items in each domain(24)) was used to QoL in gastrointestinal disease patients (25).

Electrogastrogram: Electrogastrogram (EGG) is an accurate measurement of the gastric slow waves and represents gastric motility changes. Frequency of the normal slow waves is three $(2 \pm 4)$ cycles per minute $(\mathrm{CPM})$ and abnormal data may deviate from 1 to 9 CPM. All EGG recordings were carried out after skin preparation and placement of three electrodes on the abdominal skin. The EGG signals were recorded using standard $\mathrm{Ag} / \mathrm{AgCl}$ cutaneous electrodes. The first electrode was positioned 
above the antrum (located $1 \mathrm{~cm} \pm 3$ to the right and midway between the xiphoid and the umbilicus). The second electrode was positioned 45 degrees to the left, $5 \mathrm{~cm}$ above the first electrode. The reference electrode was positioned on the right flank under the rib cage $(26,27)$. Moreover, EGG recorder and software analysis (Biopac Student Lab System, Biopac Systems, Aero Camino Goleta, CA, USA) were used to record the EGG signals using BIOPAC BSL 4.0 MP 36, Montana, USA. For the evaluation of EGG records, the following parameters were included: 1) dominant frequency, reflecting frequency of the gastric slow waves (normal range of 2-4 CPM); and 2) proportion of gastric dominant frequency, dividing into three ranges of normogastria, tachygastria (4-10 CPM) and bradygastria. In healthy participants, the normal slow-wave proportion was $\geq 70 \%$ of the recording time. Fast Fourier transforms (FFT) analysis was carried out to assess EGG changes. Recording was carried out for $30 \mathrm{~min} .{ }^{28}$ Baseline data were collected and tests were repeated after 20 days of intervention.

\section{Statistical analysis}

Shapiro-Wilk test was used to check normal distribution of data. Data analysis was carried out to assess mean differences within the baseline (pre) and endpoints (post). One-tailed two-sample paired t-test and paired t-test were used for normally distributed variables and Wilcoxon signed-rank test for variables with no normal distributions. For the comparison of data between the experimental and control groups, one-tailed two-sample t-test, one-tailed Welch's t-test and Mann-Whitney test were used. Data were analyzed using $\mathrm{R}$ Statistical Software v.3.6.0. Significance was reported if $p \leq 0.05$.

\section{Results}

Continuous variables were represented in mean $\pm \mathrm{SD}$ (standard deviation). To check normality, Shapiro-Wilk's test was used. For the mean comparisons, t-test/paired ttest, Welch's two-sample t-test was used. For data that were not under normal distribution, Wilcoxon/MannWhitney test was used. Table 1 shows the baseline assessment of demographic variables such as age and gender, which indicated that the mean of age was significantly greater in experimental group, compared to control group. Furthermore, no significant differences were seen in distribution of genders in the two groups. No significant differences were reported between pre-EGG and duration of disease within the two groups using two-tailed two-sample t-test. Furthermore, no significant differences were reported between pre-GISQ and within the two groups using Welch's t-test.

Table 1. Baseline assessments of age, gender, disease duration, GISQ and electrogastrogram

\begin{tabular}{|c|c|c|c|c|}
\hline & & \multicolumn{2}{|c|}{ Group } & \multirow{2}{*}{$P$ value } \\
\hline & & Experimental & Control & \\
\hline \multicolumn{2}{|l|}{ Age } & $34.33 \pm 9.02$ & $28.40 \pm 9.81$ & $0.0089 *$ \\
\hline \multirow[b]{2}{*}{ Gender } & Male & 10 & 14 & \multirow[t]{2}{*}{$0.291^{C h}$} \\
\hline & Female & 20 & 16 & \\
\hline \multicolumn{2}{|l|}{ Pre-EGG } & $7.25 \pm 1.25$ & $6.77 \pm 1.44$ & $0.157^{\#}$ \\
\hline \multicolumn{2}{|c|}{ Pre-GISQ } & $43.30 \pm 18.21$ & $38.23 \pm 8.38$ & $0.086^{W t}$ \\
\hline \multicolumn{2}{|c|}{ Disease duration (year) } & $0.89 \pm 0.31$ & $0.87 \pm 0.30$ & $0.773^{\#}$ \\
\hline
\end{tabular}

Table 2 shows statistical significance $(p<0.05)$ for all the variables. The table shows significant decreases in symptoms of gastritis; thus, proving efficacy of the interventions in the experimental group. Moreover, EGG demonstrates statistical significances with $p<0.0001$, meaning that the gastric motility was normalized after the interventions.

A comparison of pre-test and post-test variables of the control group in Table 3 shows no significances at 5\% level of significance as $p$-value was greater than 0.05 . It also shows no differences in symptoms within the control group. The EGG was almost constant after the interventions $(p=0.1511)$. In this study, significant differences were seen in the mean decreases of EGG scores from the the experimental group using Welch's t-test, compared to control group ( $p<0.0001$ ) (Table 4). This reveals that treatments were effective in the experimental group. The mean decreases of tachygastria was significantly less in the control group than the experimental group using two-sample t-test $(p<0.0001)$. The mean increases of normogastria scores were significantly less in the control group than the experimental group using twosample t-test $(p<0.0001)$. The mean decreses of total Izumo scores were significantly less in the control group than the experimental group. Significant differences were reported in decreases of heartburn, gastralgia, postprandial fullness, constipation, diarrhoea and GISQ of the experimental group using Mann-Whitney test, compared to the control group. This demonstrates decreses in symptoms of gastritis and effectiveness of the interventions in the experimental group. 
Swathi B.S, et al: Effect of kokum (Garcinia Indica) rind with honey on chronic gastritis

Table 2. Comparisons of pre-test and post-test parameters in the experimental group

\begin{tabular}{|c|c|c|c|}
\hline Parameter & Timepoint & Mean \pm SD/Median (Range) & p-value \\
\hline EGG & $\begin{array}{l}\text { Pre } \\
\text { Post }\end{array}$ & $\begin{array}{l}7.25 \pm 1.12 \\
3.44 \pm 0.68\end{array}$ & $<0.0001^{\mathrm{pt}}$ \\
\hline Tachygastria & $\begin{array}{l}\text { Pre } \\
\text { Post }\end{array}$ & $\begin{array}{l}66.34 \pm 8.99 \\
53.07 \pm 11.52\end{array}$ & $<0.0001^{\# \mathrm{pt}}$ \\
\hline Normogastria & $\begin{array}{l}\text { Pre } \\
\text { Post }\end{array}$ & $\begin{array}{l}10.22 \pm 5.75 \\
21.99 \pm 12.47\end{array}$ & $<0.0001^{\# \mathrm{pt}}$ \\
\hline Heartburn & $\begin{array}{l}\text { Pre } \\
\text { Post }\end{array}$ & $\begin{array}{l}4(0,14) \\
0(0,2)\end{array}$ & $<0.0001^{\mathrm{W}}$ \\
\hline Gastralgia & $\begin{array}{l}\text { Pre } \\
\text { Post }\end{array}$ & $\begin{array}{l}5(2,13) \\
0(0,2)\end{array}$ & $<0.0001^{\mathrm{W}}$ \\
\hline Postprandial fullness & $\begin{array}{l}\text { Pre } \\
\text { Post }\end{array}$ & $\begin{array}{l}6(1,15) \\
0(0,2)\end{array}$ & $<0.0001^{\mathrm{W}}$ \\
\hline Constipation & $\begin{array}{l}\text { Pre } \\
\text { Post }\end{array}$ & $\begin{array}{l}3.5(0,15) \\
0(0,2)\end{array}$ & $<0.0001^{\mathrm{W}}$ \\
\hline Diarrhea & $\begin{array}{l}\text { Pre } \\
\text { Post }\end{array}$ & $\begin{array}{l}1(0,11) \\
0(0,1)\end{array}$ & $0.000196^{\mathrm{W}}$ \\
\hline Total Izumo score & $\begin{array}{l}\text { Pre } \\
\text { Post }\end{array}$ & $\begin{array}{l}22.63 \pm 10.71 \\
1.83 \pm 1.44\end{array}$ & $<0.0001^{\# \mathrm{pt}}$ \\
\hline GISQ & $\begin{array}{l}\text { Pre } \\
\text { Post }\end{array}$ & $\begin{array}{l}43.3 \pm 18.21 \\
2.7 \pm 1.88\end{array}$ & $<0.0001^{\# \mathrm{pt}}$ \\
\hline
\end{tabular}

Abbreviations: \#pt: One-tailed two-sample paired t-test; pt: paired t-test; W: Wilcoxon-sign rank test

Table 3. Comparisons of pre-test and post-test parameters in the control group

\begin{tabular}{|c|c|c|c|}
\hline Parameter & Timepoint & Mean \pm SD/Median (Range) & p-value \\
\hline EGG & $\begin{array}{l}\text { Pre } \\
\text { Post }\end{array}$ & $\begin{array}{l}6.77 \pm 1.44 \\
6.97 \pm 1.61\end{array}$ & $0.1511^{\mathrm{pt}}$ \\
\hline Tachygastria & $\begin{array}{l}\text { Pre } \\
\text { Post }\end{array}$ & $\begin{array}{l}53.89 \pm 13.62 \\
60.78 \pm 11.16\end{array}$ & $0.0764^{\# p t}$ \\
\hline Normogastria & $\begin{array}{l}\text { Pre } \\
\text { Post }\end{array}$ & $\begin{array}{l}16.07 \pm 8.58 \\
13.11 \pm 10.8\end{array}$ & $0.0845^{\# \mathrm{pt}}$ \\
\hline Heartburn & $\begin{array}{l}\text { Pre } \\
\text { Post }\end{array}$ & $\begin{array}{l}5(0,11) \\
5(0,11)\end{array}$ & $0.7728^{\mathrm{W}}$ \\
\hline Gastralgia & $\begin{array}{l}\text { Pre } \\
\text { Post }\end{array}$ & $\begin{array}{l}5.9 \pm 1.4 \\
6.03 \pm 1.47\end{array}$ & $0.1033^{\mathrm{pt}}$ \\
\hline Postprandial fullness & $\begin{array}{l}\text { Pre } \\
\text { Post }\end{array}$ & $\begin{array}{l}4(2,10) \\
4.5(2,11)\end{array}$ & $0.2755^{\mathrm{W}}$ \\
\hline Constipation & $\begin{array}{l}\text { Pre } \\
\text { Post }\end{array}$ & $\begin{array}{l}4(0,7) \\
4(0,8)\end{array}$ & $0.2365^{\mathrm{W}}$ \\
\hline Diarrhea & $\begin{array}{l}\text { Pre } \\
\text { Post }\end{array}$ & $\begin{array}{l}3(1,6) \\
3(1,6)\end{array}$ & $0.2986^{\mathrm{W}}$ \\
\hline Total Izumo score & $\begin{array}{l}\text { Pre } \\
\text { Post } \\
\text { Post }\end{array}$ & $\begin{array}{l}23.1 \pm 3.36 \\
23.6 \pm 3.98 \\
34.3 \pm 10.69\end{array}$ & $0.06154^{\mathrm{pt}}$ \\
\hline GISQ & $\begin{array}{l}\text { Pre } \\
\text { Post }\end{array}$ & $\begin{array}{l}38.23 \pm 8.38 \\
37.63 \pm 8.18\end{array}$ & $0.2879^{\mathrm{pt}}$ \\
\hline
\end{tabular}

Abbreviations: \#pt: One-tailed two-sample paired t-test; pt: paired t-test; W: Wilcoxon sign rank test. 
Table 4. Comparisons of the parameters between the groups

\begin{tabular}{|c|c|c|c|}
\hline Parameter & Time point & Mean \pm SD/Median (Range) & p-value \\
\hline $\mathrm{EGG}^{\mathrm{R}}$ & $\begin{array}{l}\text { Experimental } \\
\text { Control }\end{array}$ & $\begin{array}{l}3.81 \pm 1.14 \\
-0.2 \pm 0.75\end{array}$ & $<0.0001^{\# \mathrm{Wt}_{\mathrm{t}}}$ \\
\hline Tachygastria $^{\mathrm{R}}$ & $\begin{array}{l}\text { Experimental } \\
\text { Control }\end{array}$ & $\begin{array}{l}13.26 \pm 11.74 \\
-6.88 \pm 11.67\end{array}$ & $<0.0001^{\text {\#t }}$ \\
\hline Normogastria ${ }^{\mathrm{I}}$ & $\begin{array}{l}\text { Experimental } \\
\text { Control }\end{array}$ & $\begin{array}{l}13.34 \pm 10.57 \\
-9.72 \pm 10.48\end{array}$ & $<0.0001^{\text {\#t }}$ \\
\hline Heartburn ${ }^{\mathrm{R}}$ & $\begin{array}{l}\text { Experimental } \\
\text { Control }\end{array}$ & $\begin{array}{l}4(0,13) \\
0(-1,1)\end{array}$ & $<0.0001^{\mathrm{MW}}$ \\
\hline Gastralgia $^{\mathrm{R}}$ & $\begin{array}{l}\text { Experimental } \\
\text { Control }\end{array}$ & $\begin{array}{l}4.5(2,11) \\
0(-1,1)\end{array}$ & $<0.0001^{\mathrm{MW}}$ \\
\hline Post prandial fullness ${ }^{R}$ & $\begin{array}{l}\text { Experimental } \\
\text { Control }\end{array}$ & $\begin{array}{l}5(0,14) \\
0(-2,1)\end{array}$ & $<0.0001^{\mathrm{MW}}$ \\
\hline Constipation $^{\mathrm{R}}$ & $\begin{array}{l}\text { Experimental } \\
\text { Control }\end{array}$ & $\begin{array}{l}3.5(-1,14) \\
0(-3,1)\end{array}$ & $<0.0001^{\mathrm{MW}}$ \\
\hline Diarrhoea $^{\mathrm{R}}$ & $\begin{array}{l}\text { Experimental } \\
\text { Control }\end{array}$ & $\begin{array}{l}1(0,11) \\
0(-1,1)\end{array}$ & $<0.0001^{\mathrm{MW}}$ \\
\hline Total Izumo score ${ }^{R}$ & $\begin{array}{l}\text { Experimental } \\
\text { Control } \\
\text { Control }\end{array}$ & $\begin{array}{l}20.8 \pm 10.03 \\
-0.5 \pm 1.41 \\
-5.03 \pm 6.63\end{array}$ & $<0.0001^{\# \mathrm{Wt}}$ \\
\hline $\mathrm{GISQ}^{\mathrm{R}}$ & $\begin{array}{l}\text { Experimental } \\
\text { Control }\end{array}$ & $\begin{array}{l}37.5(21,106) \\
0(-6,13)\end{array}$ & $<0.0001^{\mathrm{MW}}$ \\
\hline
\end{tabular}

Abbreviations: \#t: One-tailed two-sample t-test; \#Wt: One-tailed Welch's t-test; MW: Mann-Whitney test. ' $R$ ' indicates reduction was observed from pre-test to post-test and ' $I$ ' indicates increment observed from pre-test to post-test.

\section{Discussion}

This study showed significant beneficial effects of kokum rind extract with honey on symptoms of chronic gastritis, which were evident from significant decreases in tachygastric waves in EGG as well as improvements in symptoms and QoL as shown by GISQ and Izumo scale questionnaire, respectively. The improvements might be due to the neutralizing and antacid activity of garcinia, as shown in a previous study by Panda et al. They showed that neutralizing effects of Garcinia indica extract (GIE) were significantly better $(p<0.01)$ than those of water, compared to standard sodium bicarbonate in modified artificial stomach models. They also showed significant, consistent acid-neutralizing effects of GIE. Antacids neutralize gastric acid and thus help heal inflammations (13). A comparative study by Deore et al. demonstrated significant antiulcer activities of Garcinia extracts in Wistar rats $(p<0.01)$, compared to placebo. The rat ulcers were induced using indomethacin. Fruit rinds include anthocyanin, polyphenols such as garcinol, flavonoids and ascorbic acid as major chemical compounds, which are responsible for their antiulcer activities (29). In the present study, significant improvements were seen in symptoms associated to gastritis. Therefore, it can be concluded that garcinol in kokum rinds with other polyphenols includes excellent anti-ulcer activities. Yamaguchi et al. have previously shown that garcinol suppressed indomethacin induced gastric injuries in rats (30). Another study on intestinal cell lines demonstrated that garcinol significantly inhibited release of arachidonic acid from macrophages and intestinal cells with $>50 \%$ of inhibition. Garcinol inhibited nuclear factor-kappa B (NFkB) activation and cyclooxygenase $2\left(\mathrm{COX}_{2}\right)$ expression. Furthermore, it significantly inhibited nitric oxide synthase (iNOS) expression in macrophages and thus helped decrease inflammations (31).

The H. pylori is one of the major causes of gastritis, peptic ulcer and gastric cancer (32). Previous comparative studies showed similar or better bactericidal activities of garcinol against $H$. pylori at 6 and 12-h incubation times, compared to clarithromycin. Results indicated potential roles for this antioxidant in treatment for $H$. pylori infections. Garcinol plays important roles in treatment of gastric ulcers caused by $H$. pylori (33). This could be one of the reasons why improvements were seen in symptoms of chronic gastritis in the current study, as verified by GISQ. Honey is known for its antibacterial and healing properties. It includes glucose oxidase, which liberates hydrogen peroxide when diluted. The hydrogen peroxide includes bactericidal activity and enhances epithelial proliferation. The acidic $\mathrm{pH}$ of honey is a factor preventing the growth of H. pylori (10). This was shown in previous studies, where honey in combination with triple therapy was helpful to 
improve elimination rate of $H$. pylori in gastritis and duodenal ulcer patients (17). Gluconic acid, a product of glucose oxidation, is the major organic acid of honey that contributes to its acidic $\mathrm{pH}(3.2-4.5)$ (34). A study on antibacterial effects of three commercial brands of honey on $H$. pylori showed that all brands included potentially bactericidal effects on $H$. pylori, which could suscessfully be used in treatment of peptic ulcers (35). These factors contributed to the activity of honey against $H$. pylori growth and thus helped decrease symptoms and severity of chronic gastritis. This was shown in the present study as significant improvements were reported in symptoms of gastritis in the experimental group (GISQ) $(p=0.0001)$. A previous survey on Japanese patients with chronic gastritis demonstrated greater decreases in QoL of the patients with greater numbers of abdominal symptoms, using Izumo scale questionnaire (24). In the present study, improvements were recorded in all the five domains of Izumo scale questionnaire in the experimental group (Table $3)$. The $p$-values of the Izumo scale questionnaire total scores for the experimental and control groups included 0.0001 and 0.062 , respectively. It has shown that kokum rind extract in combination with honey helps improve QoL in patients with gastritis.

In this study, EGG changes were statistically significant in the experimental group after interventions $(p<0.0001)$. The FFT results showed that the dominant frequency component was improved in the experimental group after interventions (Fig. 1), showing that gastric slow waves were normalized after consumption of kokum juice with honey.

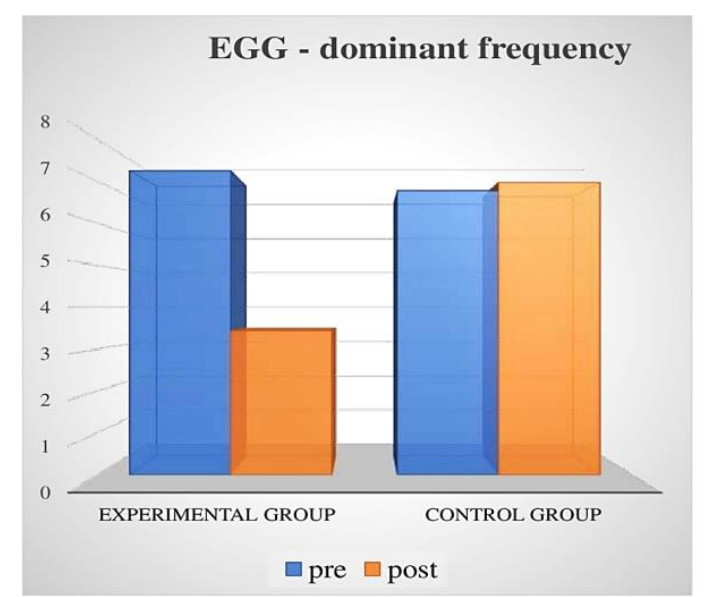

Above figure indicates that there was improvement in EGG waves after the intervention in experimental group $(\mathrm{p}<0.0001)$ and there was no much change observed in the control group after the intervention $(\mathrm{p}=0.1511)$.

Figure 1. Comparisons of the mean values of electrogastrogram (EGG) waves (dominant frequency)
In a previous study on gastric motility in 198 Japanese patients with histologic gastritis, histologic gastritis with severe inflammation were shown to possibly inhibit gastric motility (36). Another study on dysfunctions in gastric myoelectric and motor activity in $H$. pylori positive gastritis patients reported increases in tachygastria and antral hypomotility of the patients. Gastric hypomotility is linked to increased tachygastria. In patients with gastritis, higher rares of tachygastria are usually seen (37). The present study showed decreses in tachygastric and improvements in normogastric waves in the experimental group after the interventions, suggesting that consumption of kokum rind extract with honey helps improve gastric wave regularity and stability. Findings of the current study revealed that use of kokum rind extract with honey by chronic gastritis patients is beneficial to decrese severity of symptoms and improve QoL of the patients. The exact mechanism includes prevention of $H$. pylori growth, enhancement of digestion and hence prevention of further complications due to the bacteria that may lead to gastric ulcers and cancers. These effects occur due to the antibacterial, anti-inflammatory, antioxidant and bactericidal activities of kokum and honey. The strength of the present study was that this study was the first study on humans to assess effects of kokum rind extract on chronic gastritis. Use of kokum rinds is a cost-effective treatment for gastritis that can be used with no usuall side effects. No dropouts and no adverse effects occurred during the interventions of the current study. Although kokum extract and honey included antibacterial activities against $H$. pylori in this study, the bacterial activity could not be checked.

\section{Future prospects}

Study can be carried out using a larger sample size.

Long-term effects of kokum rind extract can be checked. Variables such as hydrogen breath test and serum IgG can be assessed in future studies.

\section{Conclusion}

In conclusion, consumption of kokum rind extract with honey in empty stomach for 20 days can improve symptoms of gastritis, including heartburn, gastralgia and post-prandial fullness as well as improvements in QoL of the patients. Kokum rind with honey is a cost-effective safe home-remedy to decrease symptoms of chronic gastritis

\section{Acknowledgement}

The authors express their deep gratitudes to the President of SDM Educational Society for his valuable supports. This study was self funded.

\section{Financial disclosure}

The authors declare no conflicts of interest. 


\section{References}

1. Tally NJ. Functional gastrointestinal diseases as a public health problem. Neurogastroenterology and motility 2008; 20(1):121-129.

2. Cheli R, Testino G, Giacosa A, Cornaggia M. Chronic gastritis: its clinical and physiopathological meaning. Journal of clinical gastroenterology. 1995;21(3):193-7.

3. PenttiSipponen, Heidi-Ingrid Maaroos. Chronic gastritis. Scandinavian Journal of Gastroenterology. 2015; 50(6):657667.

4. Nordenstedt H, David Y, Graham, Hashem B, El-Serag. Helicobacter pylori-Negative Gastritis: prevalence and risk factors. The American Journal of Gastroenterology. 2014; 108(1):65-71.

5. Yu LY, Sun LN, Zhang XH, Li YQ, Yu L, Meng L, et al. A review of the novel application and potential adverse effects of proton pump inhibitors. Advances in Therapy. 2017;34(5):1070-86.

6. Rai RR, Gangadhar A, Mayur M, Mayabhate. Clinical profiling of patients with Acid Peptic Disorders (APD) in India: a cross-sectional survey of clinicians. International Journal of Basic and Clinical Pharmacology. 2017; 6(1):194202.

7. Nordenstedt H, David Y, Graham, Hashem B, El-Serag. Helicobacter pylori-Negative Gastritis: prevalence and risk factors. The American Journal of Gastroenterology. 2014; 108(1): 65-71

8. Sarma YR, Babu KN, Aziz S. Spices and aromatics. Encyclopedia of Agriculture and Food System. 2014; 211 234.

9. Panda VS, Khambat PD. Antiulcer activity of Garcinia indica fruit rind (kokum berry) in rats. Biomedicine \& Aging Pathology. 2014;4(4):309-16.

10. Mandal MD, Mandal S. Honey: its medicinal property and antibacterial activity. Asian Pacific journal of tropical biomedicine. 2011;1(2):154.

11. Nayak CA, Rastogi NK, Raghavarao KS. Bioactive constituents present in Garcinia indica Choisy and its potential food applications: A review. International Journal of Food Properties. 2010;13(3):441-453.

12. Baliga MS, Bhat HP, Pai RJ, Boloor R, Palatty PL. The chemistry and medicinal uses of the underutilized Indian fruit tree Garcinia indica Choisy (kokum): a review. Food Research International. 2011;44(7):1790-1799.

13. Panda V, Khambhat P. Evaluation of antacid activity of Garcinia indica fruit rind by a modified artificial stomach model. Bulletin of Environment, Pharmacology and Life Sciences. 2013;2(7):38-42.

14. Swami SB, Thakor NJ, Patil SC. Kokum (Garcinia indica) and its many functional components as related to human health: a review. Journal of Food Research and Technology. 2014;2(4):130-142.

15. Miguel MG, Antunes MD, Faleiro ML. Honey as complementary medicine. Integrative medicine insights. 2017; 12:1-15.

16. Mato I, Huidobro JF, Simal-lozano JE, Sancho MT. Significance of nonaromatic organic acids in honey. Journal of food protection. 2003;66(12):2371-6
17. Nzeako BC, Al-Namaani F. The antibacterial activity of honey on Helicobacter pylori. Sultan Qaboos University Medical Journal. 2006;6(2):71.

18. Bovenschen HJ, Janssen MJ, Van Oijen MG, Laheij RJ, Van Rossum LG, Jansen JB. Evaluation of a gastrointestinal symptom's questionnaire. Digestive diseases and sciences. 2006;51(9):1509-1515.

19. Chakrapani C. Statistical reasoning vs. magical thinking. InProc. VUE, Mag. Marketing Res. Intell. Assoc.(MRIA) 2011 Apr (pp. 16-18). Avilable from: http://www.chuckchakrapani.com/articles/pdf/0411chakrapani .pdf.

20. Hande AR, Swami SB, Thakor NJ. Effect of drying methods and packaging materials on quality parameters of stored kokum rind. International Journal of Agricultural and Biological Engineering. 2014;7(4):114-126.

21. Hebbar J V. Kokum- Garcinia indica uses, dose, research, side effects- Easy Ayurveda. Available from: https://www.easyauyrveda.com/18/5/2015/kokum-garciniaindica-uses-dose-research-side effects (Assessed 18 March 2020).

22. Hashem-Dabaghian F, Agah S, Taghavi-Shirazi M, Ghobadi A. Combination of Nigella sativa and honey in the eradication of gastric Helicobacter pylori infection. Iranian Red Crescent Medical Journal. 2016;18(11):e23771.

23. Kellog J H. Rational hydrotherapy.2nd edition. NIN Department of AUYSH 2005. p. 931-2.

24. Kinoshita Y, Chiba T. Characteristics of Japanese patients with chronic gastritis and comparison with functional dyspepsia defined by ROME III criteria: based on the largescale survey, FUTURE study. Internal Medicine. 2011;50(20):2269-2276.

25. Kakuta E, Yamashita N, Katsube T, Kushiyama Y, Suetsugu $\mathrm{H}$, Furuta $\mathrm{K}$, et al. Abdominal symptom-related QOL in individuals visiting an outpatient clinic and those attending an annual health check. Internal Medicine. 2011;50(15):15171522 .

26. Chen J, Vandewalle J, Sansen W, Van Cutsem E, Vantrappen G, Panssens J. Observation of the propagation direction of human electrogastric activity from cutaneous recordings. Medical and Biological Engineering and Computing. 1989;27(5):538-42.

27. Asencio CM, Galvez-Arevalo LR, Almonacid ET, LandskronRamos G, Madrid-Silva AM. Evaluation of gastric motility through surface electrogastrography in critically ill septic patients. Comparison of metoclopramide and domperidone effects: a pilot randomized clinical trial. Revista de Gastroenterología de México (English Edition). 2019;84(2):149-157.

28. Rizzo G, Russo F, Indrio F. Electrogastrography in adults and children: the strength, pitfalls, and clinical significance of the cutaneous recording of the gastric electrical activity. BioMed research international. 2013.

29. Deore AB, Sapakal VD, Dashputre NL, Naikwade NS Antiulcer activity of Garcinia indica linn fruit rinds. Journal of Applied Pharmaceutical Science. 2011;1(5):151-154.

30. Yamaguchi F, Saito M, Ariga T, Yoshimura Y, Nakazawa H. Free radical scavenging activity and antiulcer activity of garcinol from Garcinia indica fruit rind. Journal of Agricultural and Food Chemistry. 2000;48(6):2320-2325. 
31. Hong J, Sang S, Park HJ, Kwon SJ, Suh N, Huang MT, et al. Modulation of arachidonic acid metabolism and nitric oxide synthesis by garcinol and its derivatives. Carcinogenesis. 2006;27(2):278-286.

32. Diaconu S, Predescu A, Moldoveanu A, Pop CS, Fierbinţeanu-Braticevici C. Helicobacter pylori infection: old and new. Journal of medicine and life. 2017;10(2):112-117.

33. Chatterjee A, Yasmin T, Bagchi D, Stohs SJ. The bactericidal effects of Lactobacillus acidophilus, garcinol, and Protykin ${ }^{\circledR}$ compared to clarithromycin, on Helicobacter pylori. Molecular and cellular biochemistry. 2003;243(1-2):29-35.

34. Samarghandian S, Farkhondeh T, Samini F. Honey, and health: A review of recent clinical research. Pharmacognosy research. 2017;9(2):121.
35. Moosa A, Kadri M. Inhibition of Helicobacter pylori by commercial honey. Medical Principles and Practice. 1994;4(2):114-116.

36. Matsumoto Y, Ito M, Kamino D, Tanaka S, Haruma K, Chayama K. Relation between histologic gastritis and gastric motility in Japanese patients with functional dyspepsia: evaluation by transabdominal ultrasonography. Journal of gastroenterology. 2008;43(5):332-337.

37. Thor P, Lorens K, Tabor S, Herman R, Konturek JW, Konturek SJ. Dysfunction in gastric myoelectric and motor activity in Helicobacter pylori-positive gastritis patients with non-ulcer dyspepsia. Journal of physiology and pharmacology: an official journal of the Polish Physiological Society. 1996;47(3):469-476. 